\title{
Immunotherapy and penis cancer
}

\begin{abstract}
Penis cancer, a cancerous disease in which malignant cells appear in the tissues of the penis. It occurs in the uncircumcised older men. It is recognized by at least two independent carcinogenic routes: virus and non-virus induced. The penis cancer is also very rare in Europe and North America. In the United States, penis cancer generally occurs in less than 1 man in 100,000 and accounts for less than $1 \%$ of cancer in men. Around half of the cancers are mainly caused by an infection with high risk human papilloma virus (hrHPV), and its main type is HPV-16. The other types of penis cancer arise, independent of hrHPV infection. The most common symptoms of penis cancer are irregular swelling at the end of the penis, a growth or sore on the penis, skin thickening on the penis, changes in the color of the penis, small and crusty bumps beneath the foreskin, reddish and velvety rash beneath the foreskin, and pain in the shaft or tip of the penis. Squamous cell or epidermoid carcinomas, basal cell carcinoma, melanoma and sarcoma are different types of penis cancers which are usually rare. The immunotherapy is a good alternative of chemotherapy for the treatment of penis cancer, but maximum drugs and therapies are under the clinical trials for FDA approval.
\end{abstract}

Keywords: penis cancer, merkel cell carcinoma, squamous cell or epidermoid carcinomas, basal cell carcinoma, melanoma and sarcoma, genital warts, penile injury, and psoralen high risk human papilloma virus (hrHPV)
Volume 7 Issue I - 2019

\author{
Timothy Allen, Shoja E Razavi, Naveed Basha \\ Court \\ Global Allied Pharmaceuticals, Center for Excellence in \\ Research and Development, USA
}

\author{
Correspondence: Timothy Allen, Global Allied \\ Pharmaceuticals, Center for Excellence in Research and \\ Development, I60 Vista Oak Dr. Longwood, FL 32779, USA, \\ Email timallenmed69@gmail.com
}

Received: December 14, 2018 | Published: January 10, 2019
Abbreviations: $\mathrm{AIN}$, anal intraepithelial neoplasias; $\mathrm{CR}$, complete response; HIV, human immunodeficiency virus; HPV, human papilloma virus; hrHPV, high risk human papilloma virus; PIN, penis intraepithelial neoplasias; RCT, randomized controlled trials; RR, recurrence rates; VIN, vulvar intraepithelial neoplasias

\section{Introduction/Epidemiology}

Penis cancer is when the malignant cells appear in the tissues of the penis. Approximately $95 \%$ of penile cancers are squamous cell carcinoma. Othertypes; of penis cancer like melanoma, small cell carcinoma, Merkel cell carcinoma are usually rare. ${ }^{1}$ The penis cancer is also very rare in Europe and North America. In the United States, penis cancer generally occurs in less than 1 man in 100,000 and accounts for less than $1 \%$ of cancer in men. However, penis cancer is much more common in some regions of South America, Africa, and Asia, where it holds for up to $10 \%$ of cancers in men. ${ }^{2}$ According to the National Cancer Institute, in the year 2014 in United States, 1,640 new cases were estimated. Additionally, in the same year, 320 death cases were also estimated. ${ }^{3}$ As per the statistical analysis, the agestandardized incidence of penis cancer is much higher in non-Western world. It signifies $10-20 \%$ of cancerous disease in men, ranging from 0.7 to 3 per 100,000 persons in India to 8.3 per 100,000 men in Brazil, and even higher in Uganda, where it is usually diagnosed. The penis cancer is a very rare cancer among all the male cancers, with higher incidences observed in between the age of 75-84 years., ${ }^{2,4}$

\section{Etiology/Predisposing Factors}

Generally, penis cancer occurs in the uncircumcised men. Circumcision is the elimination of the foreskin, and may decrease the chances of penis cancer. ${ }^{5}$ The different types of penis cancer are as follows: 5

a. Epidermoid/squamous cell carcinoma: About $95 \%$ of the penile cancers are squamous cell or epidermoid carcinomas. The epidermoid carcinoma can initiate anywhere on the penis; though, it normally develops on or under the foreskin. b. Basal cell carcinoma: Below the squamous cells in the lower epidermis, are round cells, known as basal cells and occasionally, these can transform into malignancy. It is a type of non-melanoma skin cancer, which represents less than $2 \%$ of penis cancer.

c. Melanoma: Although, this type is the rarest subtype of penile cancer, it is the one with the worst prognosis.

d. Sarcoma: Sarcoma accounts for about $1 \%$ of penis cancer. These are the cancers that develop in connective tissues, such as fat, muscles, and blood vessels.

The most common symptoms of penis cancer are irregular swelling at the end of the penis, a growth or sore on the penis, skin thickening on the penis, changes in the color of the penis, small and crusty bumps beneath the foreskin, reddish and velvety rash beneath the foreskin, and pain in the shaft or tip of the penis. ${ }^{5}$ There are common risk factors of penis cancer, such as age, smoking, HPV infection, phimosis, HIV infection, genital warts, penile injury, and psoralen UV-A chemotherapy. ${ }^{2}$

\section{Pathophysiology/Molecular basis}

In the molecular concept, the penis cancer is recognized by at least two independent carcinogenic routes: virus and non-virus induced. Around half of the cancers are mainly caused by an infection with high risk human papilloma virus (hrHPV), and its main type is HPV$16 .^{6-11}$ The other types of penis cancer arise, independent of hrHPV infection. ${ }^{12}$ However, the molecular routes of disruption vary in many ways, which is particularly related to the early genetic events and the activity of the known viral oncogenes, E6 and E7. The various common cellular pathways are disrupted at the earlier and later stages during the penis cancer, in both the virus and non-virus induced types of cancer. The penis cancer is likely to be initiated through the interference with the cellular $\mathrm{p} 16^{\mathrm{INK} 4 \mathrm{a}} /$ cyclin $^{\mathrm{D}} / \mathrm{Rb}$ pathways or $\mathrm{p} 14^{\mathrm{AER}} / \mathrm{MDM} 2 / \mathrm{p} 53$, either by viral (HPV) or non-viral (mutation) mechanism. This might result in an uncontrolled division of cells, and may also trigger a state of chromosomal instability, which further drives the carcinogenic process. The metastasis, angiogenesis, 
invasion, and expression of genes involved in disease progression, are the common molecular events that are associated with the later stages of penis cancer. ${ }^{13}$ The molecular basis of penis cancer has been explained in Table 1 below.

Table I Molecular concept of Penis cancer ${ }^{13}$

\begin{tabular}{|c|c|c|c|c|c|c|}
\hline Cancer & $\begin{array}{l}\text { Carcinogenic } \\
\text { routes }\end{array}$ & $\begin{array}{l}\text { Early molecular } \\
\text { events }\end{array}$ & $\begin{array}{l}\text { Leading to } \\
\text { disruption of }\end{array}$ & Resulting in & Later molecular events & Resulting in \\
\hline $\begin{array}{l}\text { Penis } \\
\text { Cancer }\end{array}$ & HPV induced & $\begin{array}{l}\text { Viral oncogenes, } \\
\text { hrHPV E6 and } \\
\text { hrHPV E7 }\end{array}$ & $\begin{array}{l}\mathrm{p} 14 \text { / MDM2 / p53 } \\
\text { and p16 / cyclin D / } \\
\text { CDK / Rb }\end{array}$ & $\begin{array}{l}\text { Uncontrolled cell } \\
\text { division and reduced } \\
\text { apoptosis. }\end{array}$ & $\begin{array}{l}\text { Altered gene expression involved } \\
\text { in disease invasion, progression, } \\
\text { metastasis, and angiogenesis. } \\
\text { a.o.Ras, Myc, Telomearase, } \\
\text { E-cadherin, MMPs, COX, PGE2 } \\
\text { synthase }\end{array}$ & $\begin{array}{l}\text { Immortalization, } \\
\text { Angiogenesis, } \\
\text { metastasis, and } \\
\text { invasion }\end{array}$ \\
\hline
\end{tabular}

Non-virus Oncogenes activating and/or TSG inactivating mechanism such as gene promotor methylation, gene overexpressi-on, and gene induced mutation.

\section{Immunotherapy}

\section{Monoclonal antibody}

Cetuximab: Cetuximab is an epidermal growth factor receptor (EGFR) inhibitor and a recombinant chimeric monoclonal antibody, which has been successfully used in the treatment of the Non-small cell lung cancer, colorectal cancers and squamous cell skin cancer (Non-FDA approved).

\section{Non-FDA approved MAB drugs}

Table 2

\section{Vaccine}

Non-FDA approved vaccine

Table 3

Table 2 Non-FDA approved monoclonal antibodies ${ }^{14}$

\begin{tabular}{lllll}
\hline Drug & Clinical trial identifier number & Phase & Study design & Target \\
\hline Cetuximab & NCT02014831 & Phase II & Randomized, Open Label, Safety/Efficacy Study & EGFR
\end{tabular}

Table 3 Non-FDA approved HPV vaccine ${ }^{15}$

\begin{tabular}{lllll}
\hline Drug & Clinical trial identifier number & Phase & Study design & Target \\
\hline HPV16 E7 & NCT02379520 & Phase I & Open Label, Safety Study & Cancer cells \\
\hline
\end{tabular}

Aldara immunotherapy: Aldara (Imiquimod) is a prescription medication, which works as an immune response modifier. The use of Aldara in penis intraepithelial neoplasias (PIN), vulvar intraepithelial neoplasias (VIN), and anal intraepithelial neoplasias (AIN) were supported by two cohort studies. About 15 cases have been reported for PIN, and 3 cases have been reported for AIN. There are 8 uncontrolled/ cohort studies, 9 case reports, and 2 randomized controlled trials (RCTs) for VIN. In a combined study of randomized clinical trials, uncontrolled and cohort studies, the mean complete response (CR) rates for PIN, AIN and VIN were $70 \%, 48 \%$ and $51 \%$,respectively, and the mean partial response (PR) rates for PIN, AIN, and VIN were $30 \%, 34 \%$, and $25 \%$ respectively. The recurrence (RR) rates for PIN, AIN, and VIN were $0 \%, 36 \%$, and $16 \%$, correspondingly. The followup periods for PIN, AIN, and VIN ranged from 10 to 12 months, 11 to 39 months, and 2 to 32 months, respectively. Though, the result of PIN was best between AIN and VIN. The drug, Aldara was practically well tolerated, with different side-effects being managed with decrease in the rate of drug usage. Due to these outcomes, Aldara seems to be a safe and effective drug, and as an alternate for the treatment of penis cancer. $^{16}$

\section{Adoptive Immunotherapy}

\section{Non-FDA approved adoptive therapy}

Table 4

\section{Miscellaneous}

\section{Non-FDA approved miscellaneous drugs}

Table 5

Table 4 Non-FDA approved Adoptive therapy ${ }^{19-21}$

\begin{tabular}{lllll}
\hline Drug & Clinical trial identifier number & Phase & Study design & Target \\
\hline E6 TCR & NCT02280811 & Phase II & Safety/Efficacy Study, Open Label & Cancer cells \\
Young TIL & NCT01585428 & Phase II & Non-Randomized, Open Label, Safety/Efficacy Study & Cancer cells \\
HPV 16 E7 peptide & NCT00019110 & Phase I & Treatment & Cancer cells \\
\hline
\end{tabular}


Table 5 Non-FDA approved miscellaneous drugs ${ }^{22,23}$

\begin{tabular}{llll}
\hline Drug & Clinical trial identifier number & Phase & Study design \\
\hline BBI608 & NCT01325441 & Phase I, II & Non-Randomized, Open Label, Safety/Efficacy Study \\
IGF-methotrexate & NCT02045368 & Phase I & Open Label, Safety Study stemness cell \\
\hline
\end{tabular}

\section{Conclusion}

Penis cancer has lower incidence in comparison with other cancers Penis cancer commonly affects the older men, so the treatment should not be aggressive. The immunotherapy may be a good alternative of chemotherapy for the treatment of penis cancer. Currently the modified dose and regiment of the treatments are under the clinical trials for FDA approval. HPV vaccine has been suggested as a preventive option for penile cancer. Proper pre-clinical and clinical designs of these vaccines are the important pillars in understanding the future of immunotherapy in treating cancer patients.

\section{Acknowledgments}

None.

\section{Conflicts of interest}

Authors declare that there is no conflict of interest.

\section{References}

1. Bleeker MC, Heideman DA, Snijders PJ, et al. Penile cancer: Epidemiology, pathogenesis and prevention. World Journal of Urology. 2008;27(2):141-150

2. Risk factors for penile cancer. American cancer society; 2018.

3. Penile Cancer Treatment. National Cancer Institute; 2013.

4. Colin T. Penile cancer. Patient; 2016.

5. Penile cancer guide. Cancer.Net; 2017.

6. Miralles-Guri C, Bruni L, Cubilla AL, et al. Human papillomavirus prevalence and type distribution in penile carcinoma. $J$ Clin Pathol. 2009;62(10):870-878.

7. Rubin MA, Kleter B, Zhou M, et al. Detection and typing of human papillomavirus DNA in penile carcinoma: evidence for multiple independent pathways of penile carcinogenesis. Am J Pathol. 2001;159(4):1211-1218.

8. McCance DJ, Kalache A, Ashdown K, et al. Human papillomavirus types 16 and 18 in carcinomas of the penis from Brazil. Int J Cancer. 1986;37(1):55-59.

9. Heideman DA, Waterboer T, Pawlita M, et al. Human papillomavirus-16 is the predominant type etiologically involved in penile squamous cell carcinoma. J Clin Oncol. 2007;25(29):4550-4556.

10. Gregoire L, Cubilla AL, Reuter VE, et al. Preferential association of human papillomavirus with high-grade histologic variants of penile-invasive squamous cell carcinoma. $J$ Natl Cancer Inst. 1995;87(22):1705-1709.
11. Backes DM, Kurman RJ, Pimenta, et al. Systematic review of human papillomavirus prevalence in invasive penile cancer. Cancer Causes Control. 2009;20(4):449-457.

12. Parkin DM, Bray F. Chapter 2: The burden of HPV-related cancers. Vaccine. 2006;24(3):S3/11-S3/25.

13. Rodney SN, Feber A, Muneer A, et al. Molecular Biology of Penile Cancer. In: Muneer A, Horenblas S (eds) Textbook of Penile Cancer. Springer; 2016.

14. Centre Leon Berard. Efficacy and Safety of Cetuximab in Metastatic Penile Carcinoma (PENILANE). In: ClinicalTrials.gov. Bethesda (MD): National Library of Medicine (US); 2015.

15. Baylor College of Medicine. HPV-16/18 E6/E7-Specific T Lymphocytes, Relapsed HPV-Associated Cancers, HESTIA. In: ClinicalTrials.gov. Bethesda (MD): National Library of Medicine (US); 2015.

16. Mahto M, Nathan M, O'Mahony C. More than a decade on: review of the use of imiquimod in lower anogenital intraepithelial neoplasia. Int $J$ STD AIDS. 2010;21(1):8-16.

17. Fondazione IRCCS Istituto Nazionale dei Tumori, Milano. Dacomitinib (PF-00299804) in Advanced/Metastatic Squamous Cell Carcinoma of the Penis (HER-Uro01). In: ClinicalTrials.gov. Bethesda (MD): National Library of Medicine (US); 2015.

18. Spanish Oncology Genito-Urinary Group. Study with Pazopanib and Weekly Paclitaxel in Penile Carcinoma (PAZOPEN-SOGUG). ClinicalTrials.gov. Bethesda (MD): National Library of Medicine (US); 2015 .

19. National Cancer Institute (NCI). $T$ cell Receptor Immunotherapy Targeting HPV-16 E6 for HPV-Associated Cancers. ClinicalTrials.gov. Bethesda (MD): National Library of Medicine (US); 2014.

20. National Cancer Institute (NCI). Immunotherapy Using Tumor Infiltrating Lymphocytes for Patients with Metastatic Human Papillomavirus-Associated Cancers. ClinicalTrials.gov. Bethesda (MD): National Library of Medicine (US); 2014.

21. National Cancer Institute (NCI). Vaccine Therapy in Treating Patients with Advanced or Recurrent Cancer. ClinicalTrials.gov. Bethesda (MD): National Library of Medicine (US); 2015.

22. Boston Biomedical, Inc. A Study of BBI608 Administered With Paclitaxel in Adult Patients With Advanced Malignancies. ClinicalTrials.gov. Bethesda (MD): National Library of Medicine (US); 2015.

23. University of Illinois at Chicago. Study of IGF-Methotrexate Conjugate in the Treatment of Advanced Tumors Expressing IGF-1R. ClinicalTrials.gov. Bethesda (MD): National Library of Medicine (US); 2015. 